Western North American Naturalist 68(3), C 2008, pp. 390-395

\title{
OBSERVATIONS OF SHOALING AND FEEDING BEHAVIOR OF JUNE SUCKER, CHASMISTES LIORUS, IN A REFUGE POPULATION
}

\author{
Eric J. Billman ${ }^{1,2}$
}

\begin{abstract}
Observations of shoaling and feeding behavior of the zooplanktivorous June sucker, Chasmistes liorus, were made during summer 2003 in Red Butte Reservoir, Utah. Water clarity limited observations to $0.5-1.5 \mathrm{~m}$ below the water surface. Schools of adult suckers, ranging from a few to $>200$ fish, were observed on 20 days from May to September. I classified them as schools rather than shoals because the groups moved synchronously rather than appearing simply as an aggregation of fish. These schools were near the water surface, generally in areas of the reservoir with a water depth of $>3 \mathrm{~m}$, and presumably fed on the zooplankton in the epilimnion. Juvenile suckers (age-1 and age-2) were observed only on a few occasions, near inundated vegetation. Age-0 suckers were observed in large shoals (aggregations of hundreds of fish) near the surface in the shadows of inundated vegetation in July and August. Juvenile suckers (age-0, age-1, and age-2) were always observed in age-specific shoals, while suckers in adult schools had a wider range of sizes.
\end{abstract}

Key words: Chasmistes liorus, Red Butte Reservoir, feeding behavior, shoaling, body size, Utah Lake.

The June sucker (Chasmistes liorus), endemic to Utah Lake in the Bonneville Basin, is a member of a unique group of lake suckers found in western North America (Miller and Smith 1981, Minckley et al. 1986, Scheffer 2001, Billman and Crowl 2007). Historically abundant in Utah Lake (Jordan 1891), the June sucker declined drastically through the 1900s, leading to its eventual listing as an endangered species, effective 31 March 1986 (51 FR 10857). Reasons for this decline included droughts, habitat loss, overexploitation, and negative effects of nonnative fishes, including predation. At the time of the June sucker's listing, the wild population was documented as having fewer than 1000 individuals and has been estimated to contain fewer than 500 adult suckers (Belk 1998, Keleher et al. 1998). As with other rare species, small population sizes make studies on the basic biology of a species difficult, if not infeasible (Gaston 1994).

In 1992, a refuge population was created in Red Butte Reservoir, Salt Lake County, Utah (Whitney and Belk 2000, Andersen et al. 2007, Billman and Crowl 2007). Red Butte Reservoir is located in a small narrow canyon on the west slopes of the Wasatch Mountains east of Salt Lake City, Utah. In 2003 the reservoir had a surface elevation of $1636 \mathrm{~m}$, a surface area of $4.1 \mathrm{ha}$, a mean depth of $7.8 \mathrm{~m}$, and a maximum depth of $12.2 \mathrm{~m}$ (Billman 2005). Red Butte Creek, tributary to the reservoir, exhibits an annual flow pattern characteristic of the region: high spring flows driven by snowmelt (maximum instantaneous discharge $0.623 \mathrm{~m}^{3}$. $\left.s^{-1}\right)$ followed by reduced flows derived from groundwater throughout the remainder of the year (minimum instantaneous discharge of $0.020 \mathrm{~m}^{3} \cdot \mathrm{s}^{-1}$; Ehleringer et al. 1992). During early summer, the reservoir stratifies with temperatures of approximately $20^{\circ} \mathrm{C}$ in the epilimnion and $9^{\circ}-11^{\circ} \mathrm{C}$ in the hypolimnion. The zooplankton community during summer months consists primarily of rotifer species and small cladocerans, with few copepods and large cladocerans. Bonneville cutthroat trout (Oncorhynchus clarkii utah) is the only other fish species present in the reservoir. June suckers successfully reproduced beginning 3 years after introduction, establishing a population that exceeded 13,000 age-1 and older suckers by 2004 (Billman and Crowl 2007); this self-perpetuating population provides a unique opportunity to study this otherwise rare species in a natural setting.

June suckers have been classified as midwater planktivores because of their morphology; they have terminal to subterminal mouths and branched or dendritic gill rakers that facilitate

${ }^{1}$ Department of Watershed Sciences, 5210 Old Main Hill, Utah State University, Logan, UT 84322-5210.

2Present address: Department of Biology, 401 WIDB, Brigham Young University, Provo, UT 84602. E-mail: ericbillman@gmail.com 


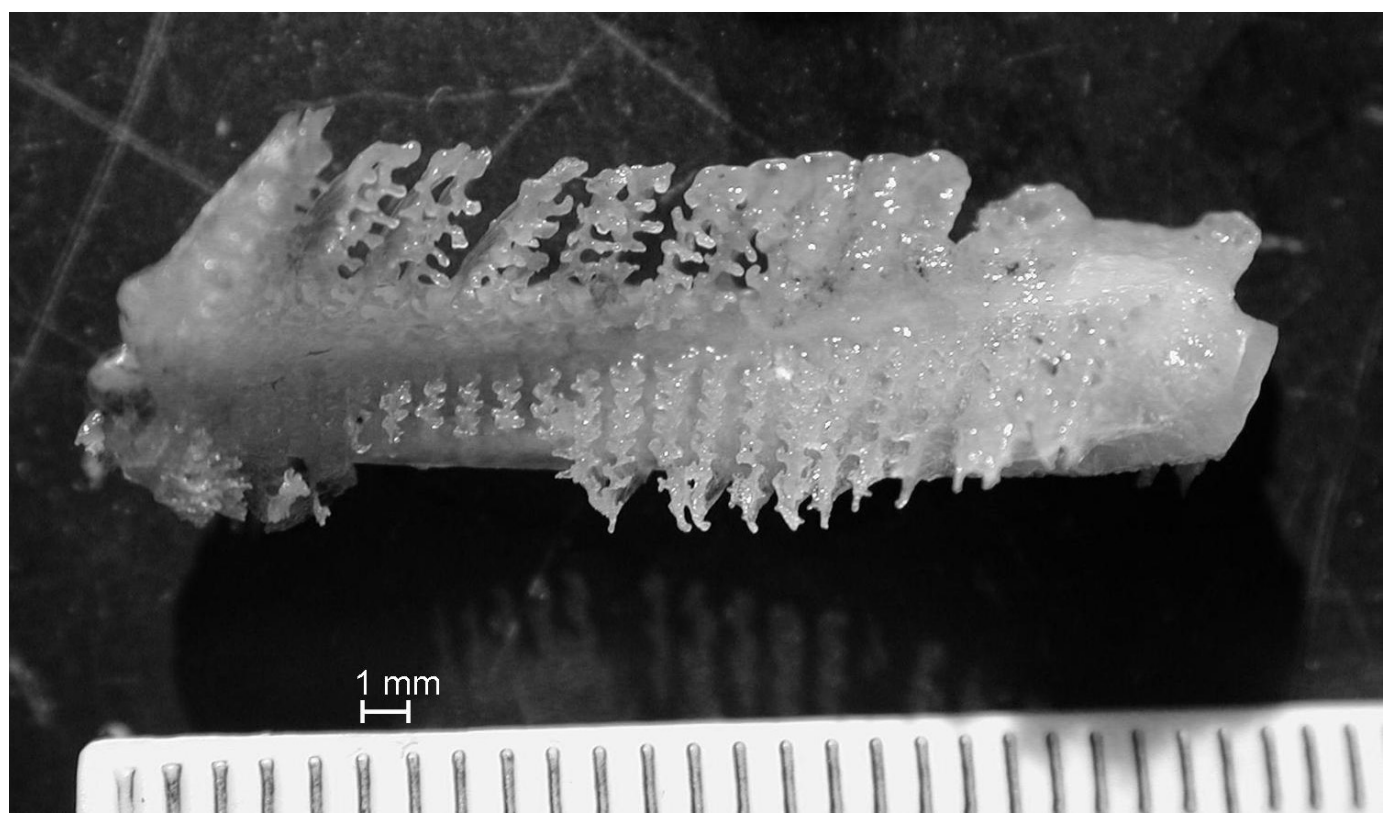

Fig. 1. Gill rakers from a male June sucker (388 mm in length) captured in Red Butte Reservoir in 2003.

zooplankton filtration (Miller and Smith 1981, Cooke et al. 2005; Fig. 1). Diet analyses of June suckers have shown that this fish is indeed a zooplanktivore (Gonzalez 2004, Billman 2005). However, not all diet analyses have indicated that the June sucker is an exclusive zooplanktivore (Thomas 1998), and it is unclear how potential hybridization with the sympatric Utah sucker (Catostomus ardens) and genetic bottlenecks have affected the June sucker's morphology and feeding habits (Mock et al. 2006). The feeding behavior of this species (i.e., whether they feed separately or in shoals; at the surface, mid-water, or benthos) has not been studied previously. Besides observations of spawning aggregations at the mouths of Utah Lake's tributaries, few observations of shoaling suckers have been documented in Utah Lake, likely due to the small sucker population in such a large lake (U.S. Fish and Wildlife Service 1999). This note documents observations of shoaling and feeding behavior in June suckers in the refuge population in Red Butte Reservoir during summer 2003.

Observations of June sucker shoals were made on 20 days from May to September. Observations were made coincidental with other June sucker research at the reservoir for 1-3 days of each week (Billman 2005, Billman and Crowl 2007). The other research was conducted throughout the reservoir during all daylight hours, providing opportunities to observe June suckers in all habitats throughout an entire day. Most observations were made from shore or boat (research was done both from shore and boat in most areas of the reservoir), but I made 3 observations while snorkeling (limited to areas along the dam and in and near the mouth of Red Butte Creek). Visibility in the water was generally poor (secchi disk depths ranged from 0.5 to $1.5 \mathrm{~m}$ ), limiting observations to the epilimnion and littoral regions of the reservoir.

Schools of adult suckers (size range of adults 300-475 mm; Billman and Crowl 2007) were observed from shore and boat on 18 days from May to early September. I refer to groups of adult suckers as schools because they moved synchronously over the time (as long as 30 minutes) and distance (as long as $200 \mathrm{~m}$ ) they were observed (Pitcher 1983). Schools ranging in size from a few fish to a couple hundred fish could be seen swimming near the surface (Fig. 2). These schools seemed to consist of only adult fish; smaller, younger fish were never seen in a school of adult fish. These schools were always moving and would occasionally switch directions or dive out of sight when 

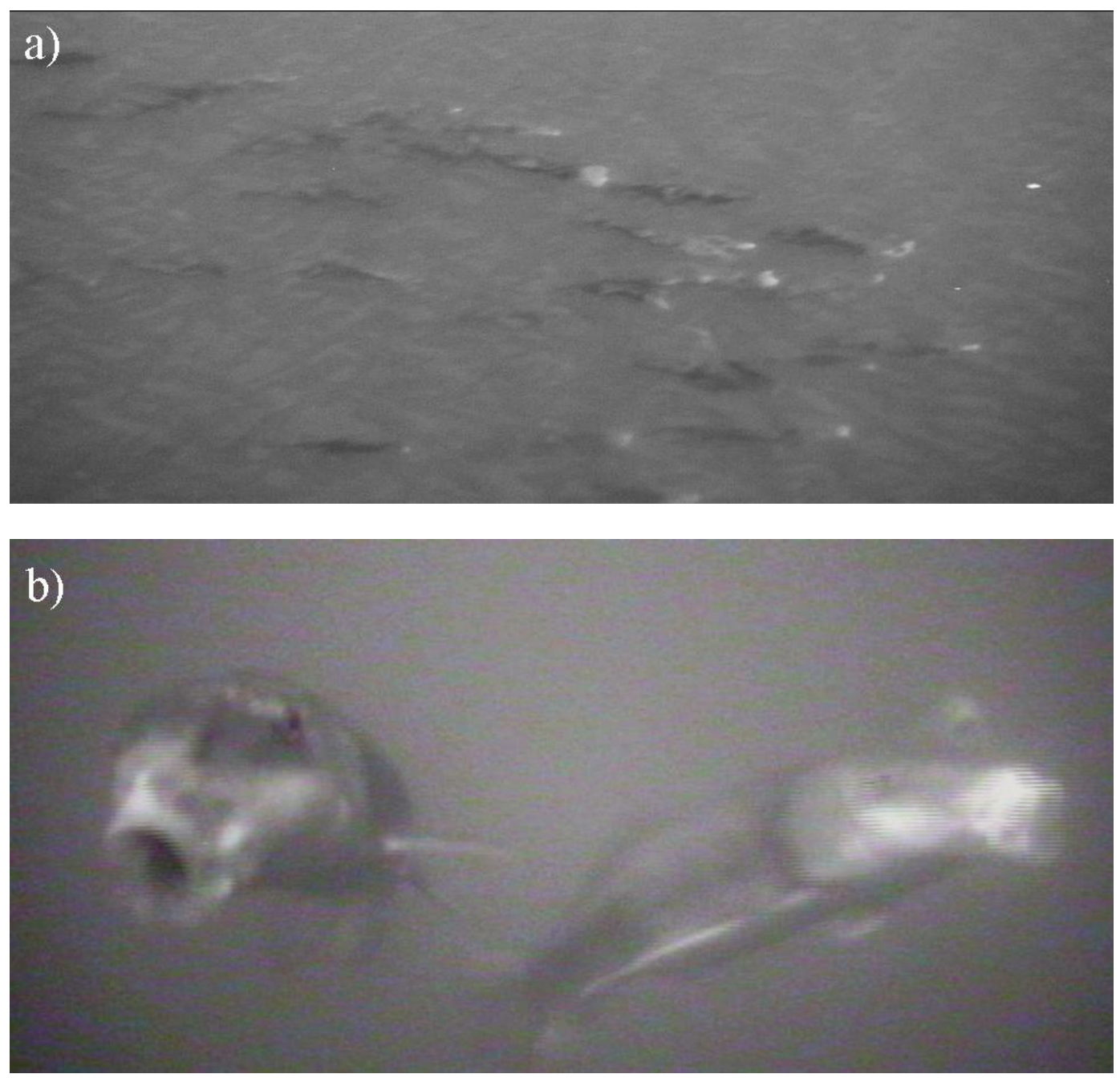

Fig. 2. School of adult June suckers near the surface of Red Butte Reservoir seen from above (a) and from underwater (b). June suckers in these schools appeared to be feeding on zooplankton.

startled (by the boat, ducks, or other unseen stimuli). Schools were generally observed in areas where water depth was $>3 \mathrm{~m}$, but occasionally these schools approached the shore (water depth $=1 \mathrm{~m}$ ) before switching directions or disappearing, presumably diving and returning to deeper water. One school was recorded with an underwater video camera; the video is available from http://www.junesuckerrecovery.org/abou-indi.html (see also Fig. 2). Schools were generally more tightly packed at the front and edges of the school (fish within 1 body length of neighbors) and more loosely packed toward the rear (distance between neighbors generally $>1$ body length). Although schools were usually cohesive groups, on a few occasions June suckers were observed leaving a school, either creating a new school or joining another school. During the month of June, the large schools of adult June suckers were not observed near the surface, because they were spawning; I observed spawning June suckers at the southeast corner of the dam from 10 June through 8 July (Billman 2005).

Adult suckers presumably school near the surface while feeding. However, fish will also aggregate near the surface if the dissolved oxygen in the water is low. Dissolved oxygen $\left(\mathrm{mg} \cdot \mathrm{L}^{-1}\right)$ was measured with a YSI 55 dissolved oxygen meter (YSI Incorporated, Yellow 
Springs, $\mathrm{OH}$ ) once every 2 weeks from 28 May to 24 July, and once per month in August and September (Billman 2005). Sampling was conducted at 2 sites in the reservoir, 1 on the east end of the reservoir (depth $=7 \mathrm{~m}$ ) and 1 on the west and deepest end of the reservoir near the dam (depth $=11 \mathrm{~m}$ ). Dissolved oxygen was $>2.0 \mathrm{mg} \cdot \mathrm{L}^{-1}$ throughout the water column and $>6.0 \mathrm{mg} \cdot \mathrm{L}^{-1}$ in the top $5 \mathrm{~m}$ at each site through 10 July. From 24 July through 20 August, the deeper west site had $<2.0 \mathrm{mg}$. $\mathrm{L}^{-1}$ dissolved oxygen in the bottom $3 \mathrm{~m}$ of the water column. The shallower east site still maintained dissolved oxygen levels $>2.0 \mathrm{mg}$. $\mathrm{L}^{-1}$ throughout the water column. Similarly, the top $5 \mathrm{~m}$ of the water column at both sites maintained dissolved oxygen levels $>5 \mathrm{mg}$. $\mathrm{L}^{-1}$. Thus, it seems unlikely that the adult sucker schools were at the surface because they were experiencing oxygen stress.

One school of age-2 suckers (size range of age-2 June suckers 145-175 mm; Billman and Crowl 2007) was observed from a boat on 2 July. This group of about 20 fish was seen at the east end of the reservoir near the mouth of Red Butte Creek. The school was observed near the surface in an area that averaged about $3 \mathrm{~m}$ deep, and the school exhibited the same directed movement as the adult suckers. The area of the reservoir where the school was observed was within $3 \mathrm{~m}$ of inundated willow and cottonwood trees. While I was snorkeling on 10 June, about 10 age-1 fish (size range of age-1 suckers 55-80 mm; Billman and Crowl 2007) were observed in the same area, within $2 \mathrm{~m}$ of shore (water depth $<0.5 \mathrm{~m}$ ). The fish were together, apparently feeding as they swam throughout the water column in and around the trunks of inundated willow trees; they only swam in a synchronous manner when they were startled. This matched the behavior of age-1 June suckers observed in 2002 that were seen swimming near and around inundated vegetation in water $<1 \mathrm{~m}$ deep (Billman 2005).

Age-0 fish (15-30 mm; Billman and Crowl 2007) were observed from both shore and boat on 8 days from mid-July through August in areas with inundated willows, particularly on the east end of the reservoir. These large shoals had hundreds if not thousands of individuals. Unlike the older suckers, which moved more freely, shoals of age-0 June suckers were stationary (observed for approximately $10 \mathrm{~min}$ utes), staying within the shadows of inundated trees and within $20 \mathrm{~cm}$ of the water surface (total water depth 1-4 m). Only when they reached larger sizes in late August could they be seen moving more freely like the age-1 shoals in the inundated vegetation along the shores.

June sucker shoals in Red Butte Reservoir were sorted by age class at least from age 0 to age 2 , demonstrating a preference in subadult June suckers for size-matched companions in shoals, similar to other species (Hoare et al. 2000). Schools of adult suckers had greater size variation (see range above) because this stage-class encompasses multiple age classes, and there was no indication from my observations that they were shoaling by sex. Such size discrimination in shoal selection, as observed in juvenile June suckers, is thought to result from predation risk and competition. Predation risk is thought to be higher for individuals whose phenotype (body size in this case) differs from the other members of the group, also known as the oddity effect. Similarly, large fish are more competitive and have higher foraging rates than small fish; thus, small fish should avoid shoals with large individuals (Hoare et al. 2000). Size discrimination in shoals can also occur because of ontogenetic changes in habitat utilization (Werner and Hall 1988). Smaller, younger June suckers were only observed in areas with structure provided by inundated vegetation, particularly age-0 suckers that were hiding in the shadows. These areas likely provided refuge from potential predators (i.e., cutthroat trout). Larger June suckers were no longer at risk from the gape-limited cutthroat trout and were able to use pelagic habitat, where foraging can be more optimal (Werner and Hall 1988).

The prevalence of shoaling in all ages of June sucker indicates that individual fish benefit from this social behavior, although benefits likely differ with size or age. Younger, smaller fish in shoals likely benefit from reduced risk of predation by Bonneville cutthroat trout. Shoaling reduces predation risk in 2 ways: many eyes to spot predators and the dilution effect (Parrish 1993, Moyle and Cech 2004). When in a shoal, individual fish can spend more time feeding and less time watching for predators because there are more eyes to spot potential predators. Similarly, the dilution effect, or the safety in numbers concept, reduces the probability that any 1 individual will be eaten. Large 
adult fish would not receive this same benefit as they are virtually predator-free in Red Butte Reservoir. The only avian predators I observed were mallard ducks (Anas platyrhynchos; potential predator to juvenile suckers); other avian predators were not observed during the period when observations were made, nor have they been historically documented in the canyon during summer months (Ehleringer et al. 1992). Instead, these larger fish likely benefit from increased foraging efficiency. Schooling in planktivorous fish increases the probability of detecting suitable patches of plankton because of the presence of many eyes searching a larger area than a single individual can search. Indeed, studies have shown that foraging success in planktivores can be increased by the formation of groups (Morgan 1988, Ranta and Kaitala 1991, Milne et al. 2005). However, fish in the rear of a school are likely to encounter lower densities of plankton than those in the front. This may explain the shape of adult schools, which were more tightly grouped and denser at the front and edges compared to the middle and rear of the school.

Poor survival of juvenile June suckers in Utah Lake has been attributed to the loss of structure provided by macrophytes, thus making juvenile suckers more susceptible to predation (Petersen 1996, Belk et al. 2001). Submerged aquatic vegetation has decreased throughout Utah Lake due to water fluctuations from irrigation and effects of foraging behavior of introduced carp, Cyprinus carpio, which have become the most abundant fish in the lake since their introduction (U.S. Fish and Wildlife Service 1999, Miller and Crowl 2006). The use of macrophytes by June suckers has been demonstrated in a laboratory setting (Petersen 1996), and juvenile suckers have been observed in vegetated areas near the mouth of the Provo River in Utah Lake (J. Rasmussen personal communication). The observations of June suckers in Red Butte Reservoir confirm that juvenile suckers do indeed use submerged vegetation for structure. However, my sampling was not exhaustive enough to indicate whether or not vegetated littoral regions were utilized exclusively by juvenile suckers.

These observations of shoaling and feeding behavior of June suckers in Red Butte Reservoir provide new insight into the basic biology of this species. These behaviors were poorly documented primarily due to small population sizes in Utah Lake. If shoaling behavior in June suckers decreases predation risk and increases foraging success, as it does in other species (Hoare et al. 2000, Milne et al. 2005), small population sizes could further threaten this species because they could lose the benefits of this social behavior (i.e., Allee effects; Berec et al. 2007). Further studies on the schooling behavior and the possible Allee effect in June sucker due to a reduced population size in Utah Lake could contribute greatly to the recovery of June suckers.

Chris Keleher made the 1st observations of June sucker shoaling behavior in Red Butte Reservoir, which led me to observe and take note of this behavior. Dave Kikkert and Todd Crowl helped in making observations and capturing video footage of the June suckers. Funding was provided by the June Sucker Recovery Implementation Program through the Central Utah Water Conservancy District. Additional funds were provided by the Ecology Center at Utah State University. The United States Forest Service provided access to Red Butte Reservoir. Mark Belk, Josh Rasmussen, and Chris Keleher provided helpful comments on the manuscript.

\section{Literature Cited}

Andersen, M.E., C.J. Keleher, J.E. Rasmussen, E.S. Hansen, P.D. Thompson, D.W. Speas, M.D. RoutLEDGE, AND T.N. Hedrick. 2007. Status of June sucker in Utah Lake and refuges. Pages 39-58 in M.J. Brouder and J.A. Scheurer, editors, Status, distribution, and conservation of native freshwater fishes of western North America: a symposium proceedings. American Fisheries Society, Symposium 53, Bethesda, MD.

BELK, M.C. 1998. Age and growth of June sucker (Chasmistes liorus) from otoliths. Great Basin Naturalist 58:390-392.

Belk, M.C., M.J. Whitney, And G.B. Schaalje. 2001. Complex effects of predators: determining vulnerability of the endangered June sucker to an introduced predator. Animal Conservation 4:251-256.

Berec, L., E. Angulo, And F. Courchamp. 2007. Multiple allee effects and population management. Trends in Ecology and Evolution 22:185-191.

Billman, E.J. 2005. Population dynamics and foraging ecology of a June sucker (Chasmistes liorus) refuge population. Master's thesis, Utah State University, Logan.

Billman, E.J., And T.A. Crowl. 2007. Population dynamics of a June sucker refuge population. Transactions of the American Fisheries Society 136:959-965.

Cooke, S.J., C.M. Bunt, S.J. Hamilton, C.A. Jennings, M.P. Pearson, M.S. Cooperman, and D.F. Markle. 2005. Threats, conservation strategies, and prognosis 
for suckers (Catostomidae) in North America: insights from regional case studies of a diverse family of nongame fishes. Biological Conservation 121:317-331.

Ehleringer, J.R., L.A. Arnow, T. Arnow, I.B. McNulty, and N.C. Negus. 1992. Red Butte Canyon Research Natural Area: history, flora, geology, climate, and ecology. Great Basin Naturalist 52:95-121.

Federal Register [51 FR 10857]. 1986. Endangered and threatened wildlife and plants; final rule determining June sucker (Chasmistes liorus) to be an endangered species with critical habitat. Volume 51(61):1085110857.

Gaston, K.J. 1994. Rarity. Chapman and Hall, London.

GonZÁlez, D.B. 2004. Density effects on growth, survival and diet of June suckers (Chasmistes liorus): a component Allee effect in an endangered species. Master's thesis, Brigham Young University, Provo, UT.

Hoare, D.J., J. Krause, N. Peuhkuri, and J.-G.J. Godin. 2000. Body size and shoaling in fish. Journal of Fish Biology 57:1351-1366.

JORDAN, D.S. 1891. Report of exploration in Colorado and Utah during the summer of 1889 , with an account of the fishes found in each of the river basins examined. United States Fisheries Commission Bulletin 9:1-40.

Keleher, C.J., L.D. Lentsch, And C.W. Thompson. 1998. Evaluation of flow requirements for June sucker (Chasmistes liorus) in the Provo River: an empirical approach. Publication Number 99-06. Utah Division of Wildlife Resources, Salt Lake City.

Miller, R.R., and G.R. Smith. 1981. Distribution and evolution of Chasmistes (Pisces: Catostomids) in western North America. Occasional Papers 696. Museum of Zoology, University of Michigan, Ann Arbor.

Miller, S.A., AND T.A. Crowl. 2006. Effects of common carp (Cyprinus carpio) on macrophytes and invertebrate communities in a shallow lake. Freshwater Biology 51:85-94.

Milne, S.W., B.J. Shuter, and W.G. Sprules. 2005. The schooling and foraging ecology of lake herring (Coregonus artedi) in Lake Opeongo, Ontario, Canada. Canadian Journal of Fisheries and Aquatic Sciences 62:1210-1218.

Minckley, W.L., D.A. Hendrickson, and C.E. Bond. 1986. Geography of western North American freshwater fishes: description and relationships to intra- continental tectonism. Pages 519-614 in C.H. Hocutt and E.O Wiley, editors, The zoogeography of North American freshwater fishes. John Wiley \& Sons, Inc., New York.

Mock, K.E., R.B. Evans, M. Crawford, B.L. Cardell, S.U. Janeckes, AND M.P. Miller. 2006. Rangewide molecular structuring in the Utah sucker (Catostomus ardens). Molecular Ecology 15:2223-2238.

Morgan, M.J. 1988. The influence of hunger, shoal size, and predator presence on foraging in bluntnose minnows. Animal Behavior 36:1317-1322.

Moyle, P.B., And J.J. Cech, JR. 2004. Fishes: an introduction to ichthyology. 5th edition. Prentice Hall, Upper Saddle River, NJ.

Parrish, J.K. 1993. Comparison of hunting behavior of four piscine predators attacking schooling prey. Ethology 95:233-246.

Petersen, M.E. 1996. The effects of prey growth, physical structure, and piscivore electivity on the relative prey vulnerability of gizzard shad (Dorosoma cepedianum) and June sucker (Chasmistes liorus). Master's thesis, Utah State University, Logan.

Pitcher, T.J. 1983. Heuristic definitions of fish shoaling behaviour. Animal Behaviour 31:611-613.

Ranta, E., and V. Kaitala. 1991. School size affects individual feeding success in three-spined sticklebacks (Gasterosteus aculeatus L). Journal of Fish Biology 39:733-737.

SCHEFfER, M. 2001. Ecology of shallow lakes. Kluwer Academic Publishers, Dordrecht, The Netherlands.

Thomas, H.M. 1998. Effects of habitat structure on predator-prey interactions between introduced white bass and endangered June sucker. Doctoral dissertation, Utah State University, Logan.

U.S. Fish And Wildlife SERvice. 1999. June sucker (Chasmistes liorus) recovery plan. U.S. Fish and Wildlife Service, Denver, CO.

Werner, E.E., AND D.J. HaLl. 1988. Ontogenetic habitat shifts in bluegill: the foraging rate-predation risk trade-off. Ecology 69:1352-1366.

Whitney, M., AND M.C. BeLK. 2000. Threatened fishes of the world: Chasmistes liorus Jordan, 1878 (Catostomidae). Environmental Biology of Fishes 57:362.

Received 3 October 2007 Accepted 5 February 2008 